\title{
EARLY SHUNT COMPLICATIONS IN 46 CHILDREN WITH HYDROCEPHALUS
}

\author{
Moisés Heleno Vieira Braga', Gervásio Teles C. de Carvalho², \\ Rafael Augusto Castro Santiago Brandão?, \\ Franklin Bernardes Faraj de Lima', Bruno Silva Costa ${ }^{2}$
}

\begin{abstract}
Objective: To determine the causes of early shunt complications in 46 children with hydrocephalus. Method: A retrospective study was conducted on 46 children submitted to ventriculoperitoneal shunt surgery between February 2005 and February 2007. Results: Thirteen (28\%) patients presented complications, which were due to infection in $9(69 \%)$ and to malfunction of the shunt system in $4(31 \%)$. The mean number of surgical procedures performed on patients who presented complications was 2.8 per patient, with a total of 46 surgeries in this group. All patients with infectious complications were identified during their hospital stay. Conclusions: Infection was the most common complication. The infection rate was proportional to the length of hospital stay. All patients with hydrocephalus due to tumors or myelomeningocele presented complications. A higher incidence of infections was observed in children older than 2 years.
\end{abstract}

KEY WORDS: hydrocephalus, hydrocephalus valve, ventriculoperitoneal shunt, ventriculoatrial shunt, early complications.

\section{Complicações precoces de válvula de hidrocefalia em 46 crianças}

Resumo - Objetivo: Determinar e as causas das complicações precoces nas válvulas de hidrocefalia de 46 crianças. Método: Um estudo retrospectivo foi realizado com 46 crianças submetidas a colocação de válvula de hidrocefalia no período de fevereiro de 2005 a fevereiro de $2007 . \quad$ Resultados: Obtivemos 13 (28\%) pacientes com complicações sendo 9 (69\%) causadas por infecção e 4 (31\%) por mal funcionamento da válvula de hidrocefalia. A média de procedimentos cirúrgicos realizados nos pacientes com complicações foi de 2,8 por paciente, sendo o total de 46 cirurgias neste grupo. Todos os pacientes com complicações infecciosas foram detectados durante a internação hospitalar. Conclusões: Infecção foi a complicação mais comum. $O$ índice de infecção foi proporcional ao tempo de permanência hospitalar. Todos os pacientes portadores de hidrocefalia secundária a tumores ou mielomeningocele complicaram. As crianças maiores de 2 anos de idade tiveram maior incidência de infecções.

PALAVRAS-CHAVE: hidrocefalia, válvula de hidrocefalia, derivação ventrículo-peritoneal, derivação ventrículoatrial, complicações precoces.

Since the 1950s, shunt systems including ventriculoperitoneal (VP) and ventriculoatrial (VA) have been effectively used for the surgical treatment of hydrocephalus. The main complication of this type of treatment is infection, which can cause severe complications such as cognitive and neurological deficits. There are several risk factors that contribute to the development of VP shunt infections, such as secondary hydrocephalus, premature baby, a history of meningitis, lack of experience of the sur- gical team, prolonged duration of surgery, presence of a cerebrospinal fluid (CSF) fistula, scalp necrosis, and perforation or infection of abdominal viscera, among others.

The main causative agents of shunt infections are Staphylococcus epidermidis (52.8 to 88.9\%), Staphylococcus aureus ( 12 to $40 \%$ ), Gram-negative bacilli (9 to $22 \%$ ), enterobacteria, Klebsiella pneumoniae, and Pseudomonas aeruginosa'.

Another important cause of complications is dysfunc- 
tion of the hydrocephalus valve. Obstruction of the proximal catheter is the main mechanism responsible for a malfunctioning shunt. In this respect, obstruction with choroid plexus fragments, debris and intraventricular glial tissue and inadequate insertion of the proximal catheter inside the cerebral parenchyma or at the border of the ventricular wall contribute to inadequate CSF drainage'.

VP shunt infection rates range from 0 to $31.4 \%$, with a mean of 10 to $15 \%$. VP shunt procedures present higher complication rates than endoscopic third ventriculostomy, but the latter is mainly indicated in selected cases of obstruction of the Sylvian aqueduct or of the fourth ventricle.

The objective of the present study was to determine the causes of early shunt complications in 46 children with hydrocephalus.

\section{METHOD}

A retrospective study was conducted on 46 children submitted to VP shunt surgery between February 2005 and February 2007 at the Neurosurgery Service of Santa Casa de Misericórdia, Belo Horizonte, Brazil.

The following data were obtained from the records of children with history of hydrocephalus, VPS, external ventricular drain, meningitis, and ventriculitis: cause of hydrocephalus, days of postoperative hospitalization, CSF analysis, date of surgery, age, and gender. Infection and shunt dysfunction were classified as complications. Infection was defined as the presence of postoperative fever and leukocytosis and neutrophilia in blood and CSF.

All children were submitted to postoperative cranial computed tomography (CT). Patients older than 13 years were excluded. Data of patients followed up for one month after surgery were included in the study. The sample consisted of two cases of VA shunts and 44 cases of VP shunts.

The variables are reported as absolute and relative frequencies and as the mean and standard deviation. The results were analyzed using the chi-square test $\left(\chi^{2}\right)$, Fisher's exact test and relative risk. The $95 \%$ confidence limits were calculated using the Epi-Info 2004 program.

\section{RESULTS}

The study population consisted of 46 patients ranging in age from 0 to 13 years. The distribution of the patients according to age is shown in Table 1.
Table 1. Age of the children submitted to surgery.

$\begin{array}{cc}<2 \text { years } & 20(43.4 \%) \\ 2 \text { to } 7 \text { years } & 24(52 \%) \\ >7 \text { years } & 2(4.6 \%)\end{array}$

Table 2. Initial infectious manifestations.

\begin{tabular}{cc}
\hline Fever & $6(67 \%)$ \\
Fistula & $2(22 \%)$ \\
Prostration & $1(11 \%)$ \\
Total & $9(100 \%)$ \\
\hline
\end{tabular}

Table 3. Relationship between age and complications.

\begin{tabular}{lcc}
\hline Age & Complications & No complications \\
\hline$<2$ years $(n=20)$ & $5(25 \%)$ & 15 \\
$>2$ years $(n=26)$ & $8(30.7 \%)$ & 18 \\
Total $(n=46)$ & $13(28 \%)$ & 33 \\
\hline
\end{tabular}

$\chi^{2}=49 ; p=0.001$.

A total of 98 surgical procedures were performed, corresponding to 1.5 surgeries per patient.

Shunt complications were observed in $13(28 \%)$ of the 46 patients, including dysfunction in four $(31 \%)$ and infection in nine (69\%). Signs and symptoms of infection are shown in Table 2. Among the four cases of shunt dysfunction, one (25\%) was caused by malfunction of the system and three $(75 \%)$ were due to poor placement of the proximal catheter.

Analysis of the relationship between age and complications showed a significantly higher rate of infection $(p=0.001)$ among children older than 2 years (Table 3), a finding that is in contrast to literature data ${ }^{2,3}$.

Complications were more frequent among patients with primary hydrocephalus $(8 / 13,61 \%)$. Hydrocephalus secondary to a tumor or myelomeningocele was responsible for complications in five $(38.46 \%)$ of the 13 patients with shunt complications. However, this result was inverted when we analyzed the number of complications in relation to the total number of patients. Forty-one of the

Table 4. Relationship between the cause of hydrocephalus and complications.

\begin{tabular}{lccc}
\hline Cause of hydrocephalus & Complications & No complications & Total \\
\hline Primary hydrocephalus & $8(19.5 \%)$ & 33 & 41 \\
Myelomeningocele & $3(100 \%)$ & 0 & 3 \\
Tumor & $2(100 \%)$ & 0 & 2 \\
Total & 13 & 33 & 46 \\
\hline
\end{tabular}

$\chi^{2}=20.164 ; p<0.001$. 
Table 5. Brazilian series investigating shunt infections in patients with hydrocephalus.

\begin{tabular}{lcccc}
\hline Reference & Place & Year & Total & Infection \\
\hline Figueiredo et al. & Ceará & 1981 & 92 & $17.4 \%$ \\
Salomão et al. & IFF Rio & 1993 & 142 & $11.8 \%$ \\
Jucá et al. $^{8}$ & USP RP & 2002 & 150 & $15 \%$ \\
Araujo et al. $^{10}$ & Santa Casa do Pará & 2004 & 191 & $45 \%$ \\
Kliemann et al. $^{6}$ & Santa Casa SP & 2005 & 243 & $22.3 \%$ \\
Lima et al. $^{4}$ & HGJAF Aracaju & 2007 & 58 & $27.6 \%$ \\
\hline
\end{tabular}

46 patients had primary hydrocephalus and only eight of them (19.5\%) presented complications. In contrast, five of the 46 patients studied had secondary hydrocephalus, with complications being observed in all of them (Table 4).

Complications were observed in all patients who were hospitalized for 15 days or more, with the diagnosis of complications being made, on average, at 9.3 days.

\section{DISCUSSION}

Infection is the main immediate postoperative complication observed in patients submitted to VP shunting. An infection rate of $19.5 \%$ was found in the present study. This value is high but is still within the rates reported in the literature which range from 3 to $30 \%^{2,3}$.

If patients with myelomeningocele and brain tumors were excluded from the present sample, the infection rate falls to about $10 \%$.

Infection rates are much higher in these patients than in those with congenital hydrocephalus because the former normally require a longer period of hospitalization and many of them develop other clinical complications such as pneumonia and urinary infection which markedly increase the risk of VP shunt infections ${ }^{2,3}$. According to the literature, 70 to $80 \%$ of shunt infections occur within the first postoperative month and $15 \%$ occur from the first to the ninth postoperative month ${ }^{4}$.

Lima et al. ${ }^{4}$ reported a surgical infection rate of $27.6 \%$ $(16 / 58)$ per surgical procedure and of $32 \%(16 / 50)$ per patient, with about $80 \%$ of cases being diagnosed within the first postoperative month. Since the present patients were only studied for a short period of time, our infection rate is probably higher than reported in that study ${ }^{3}$. However, in view of the difficulties encountered at Brazilian public hospitals and considering a value of $10 \%$ observed in patients with primary hydrocephalus, this rate is within an acceptable, although not ideal, limit ${ }^{5}$.

Studies on this subject are scarce in the Brazilian literature. In a search of the Bireme and LILACS databases, we found six series conducted at Brazilian public hospitals. All series shown in Table 5 report infection rates higher than $10 \%$, reaching a rate of $45 \%$. These figures are a matter of concern and have been poorly discussed ${ }^{6-10}$.

In the present study, all patients who were hospitalized for more than 15 days developed infectious complications of the shunt system. Despite the small sample size, our results suggest that the duration of hospitalization is associated with VPS infection by increasing the possibility of bacterial colonization. In a recent study, Thompson et al." suggested that, in contrast to common views, the time of susceptibility to infection extends much beyond the time of surgery. In fact, most pathogenic agents responsible for infection were not only isolated from the surgical field but also during exposure and cleaning of the surgical wound. This reinforces the need to reduce the duration of hospitalization and to maintain special surgical wound care".

Some investigators $5^{5,12}$ have reported an important association between child's age of less than 6 months and infection of the shunt system, whose frequency was 2.6 times higher than in children older than one year. Other studies did not find differences in the infection rate between different children's ages ${ }^{13}$. An increased risk of infection was only demonstrated among premature children ${ }^{5}$. In contrast to the literature, we observed a greater predominance of complications in the age group of 2 to 7 years.

In a prospective study, Kulkarni et al. ${ }^{5}$ identified three basic risk factors for VPS infections: presence of a CSF fistula, excessive contact with the prothesis, and child's age. The authors suggested the simultaneous use of double gloves to reduce the risk related to shunt manipulation.

In the present study, the frequency of shunt dysfunction was $8.7 \%$. We found no articles reporting the rate of shunt dysfunction only during the immediate postoperative period. The rate of late dysfunction has been shown to be high, reaching $40 \%$ within 2 years ${ }^{3}$. Gupta et al. ${ }^{14}$ demonstrated that patients who had shunts for more than 10 years presented a system malfunction rate of about $80 \%$. Of these, $54 \%$ were submitted to four or more changes of the shunt system.

Other less frequent types of complications such as excessive drainage, cysts and abscesse $\mathrm{s}^{3,15,16}$ were not ob- 


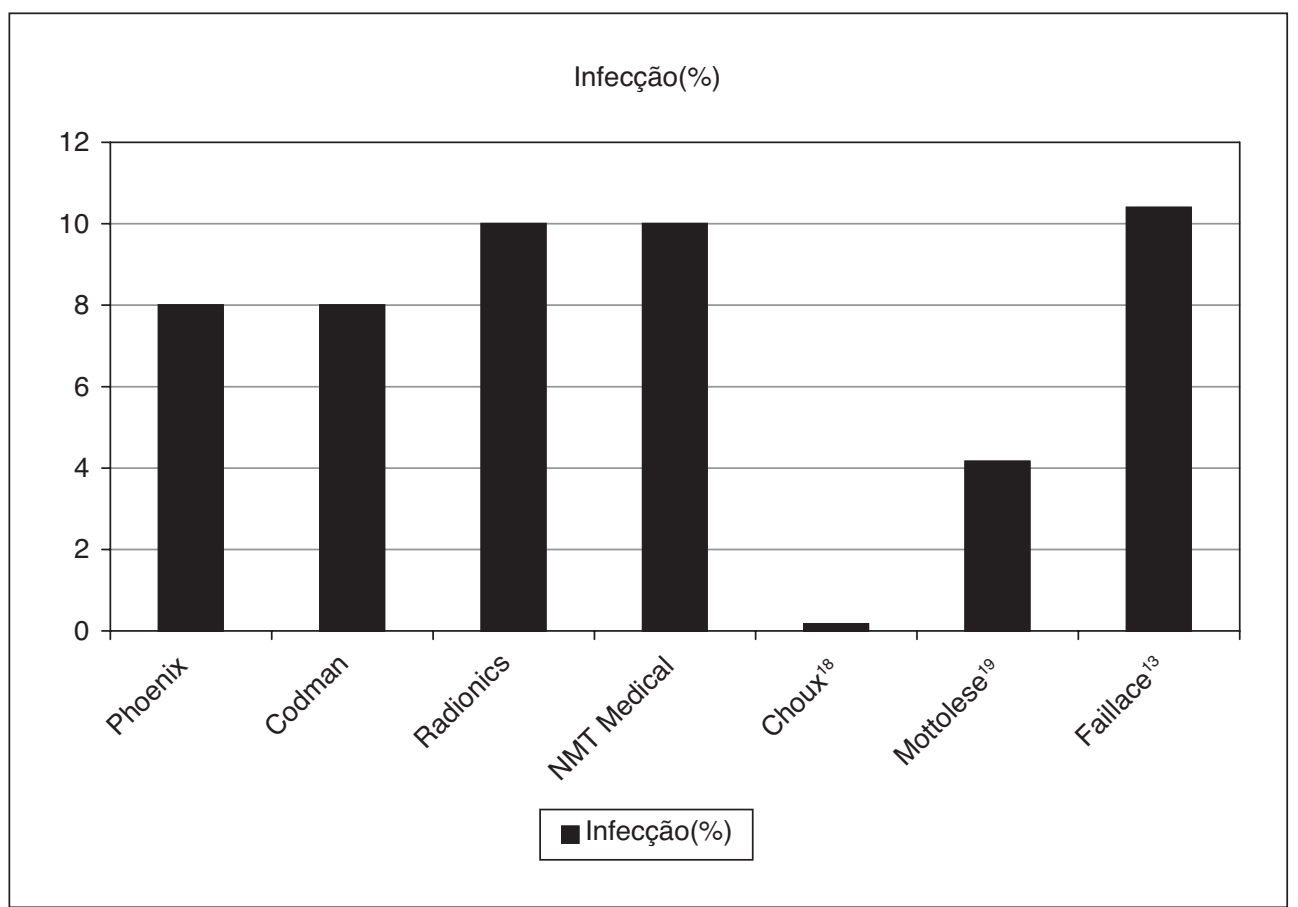

Figure. Four different valve brands and their respect infection rate (in \%) compared to other VP shunt reviews published in Europe.

served in the present investigation, probably because of the short study period. In a large retrospective study comprising all patients operated upon in California between 1990 and 2000, the rate of VPS complications reached $46.4 \%$ during the period ${ }^{16}$.

We emphasize the need to reduce the frequency of VPS infections at our service and to investigate possible risk factors in a controlled prospective study.

The frequency of shunt infections is associated with the experience of the surgeon ${ }^{10,16}$. In a study comparing the rate of VPS infections during different periods of the year in Canada, Kestle et al. ${ }^{17}$ observed an increased trend of infections after the arrival of new residents, but the difference was not significant. Choux et al. ${ }^{18}$ demonstrated that preoperative measures such as a better selection of indications, adequate skin preparation with disinfecting baths and a standardized surgical technique drastically reduce the level of infection. Using a similar protocol, Mottolese et al..$^{19}$ also significantly reduced the rate of infection. However, subsequent studies were unable to reproduce these results.

Antibiotic-impregnated shunts or different shunt systems have not improved the rates of complication ${ }^{20}$. Costa and Maitrot ${ }^{20}$, using 77 VPS from four different manufacturers in France, did not observe significant differences in infection rates compared to the rates reported in other European studies (Figure)

In conclusion, infection was the most common early shunt complication in patients with hydrocephalus, with the infection rate being proportional to the length of hospital stay. All patients with hydrocephalus secondary to tumors or myelomeningocele developed infections, a fact demonstrating that associated comorbidities are important risk factors. The high infection rate observed is compatible with other Brazilian studies and is much higher than that desired. Further efforts are necessary to identify the causes and to establish measures to reduce these rates.

\section{REFERENCES}

1. Sarguna P, Lakshmi V. Ventriculoperitoneal shunt infections. Indian Med Microbiol 2006;24:52-54.

2. Pople IK, Bayston R, Hayward RD. Infection of cerebrospinal fluid shunts in infants: a study of etiological factors. J Neurosurg $1992 ; 77: 29-36$.

3. Drake JM, Kestle JRW, Milner R. Randomized trial of cerebrospinal fluid shunt valve design in pediatric hydrocephalus. Neurosurg 1998;43:294-303.

4. Lima MMM, Pereira CU, Silva AM .Infecções em dispositivos neurológicos implantáveis em crianças e adolescentes. Arq Neuropsiquiatr 2007;65:118-123.

5. Kulkarni AV, Drake JM, Lamberti-Pasculli M. Cerebrospinal fluid shunt infection: a prospective study of risk factors. J Neurosurg 2001;94:195-201.

6. Kliemann SE, Rosemberg S. Hidrocefalia derivada na infancia. Um estudo clínico-epidemiológico de 243 observações consecutivas. Arq Neuropsiquiatr 2005;63:494-501.

7. Salomão JF, Leibinger RD, Menezes MLB, Carvalho JGS. 
Infecçäo nas derivaçöes ventriculares em uma população pediátrica. Arq Bras Neurocir 1993;12:255-264.

8. Jucá CEB, Neto AL, Oliveira RS, Machado HR. Treatment of hydrocephalus by ventriculoperitoneal shunt: Analysis of 150 consecutive cases in the Hospital of the Faculty of Medicine of Ribeirão Preto. Acta Cirúrg Bras 2002;17:59-64.

9. Figueiredo DG, Carvalho FF. Complications in the treatment of hydrocephalus by the use of shunts. A study of 92 cases. Neurobiologia 1981;44:193-206.

10. Araújo EC, Carvalho AH, Essashika EFIA, Moraes AN, Damasceno ACA. Hidrocefalia em crianças hospitalizadas na Santa Casa de Misericórdia. Rev Med 2004;18:24-29.

11. Thompson DN, Hartley JC, Hayward RD .Shunt infection: is there a near-miss scenario? J Neurosurg 2007;106:1:15-19.

12. Dallacasa P, Dappozzo A, Galassi E, Sandri F, Cocchi G, Masi M. Cerebrospinal fluid shunt infections in infants. Child's Nerv Syst 1995;11:643-648.

13. Faillace WJ. Shunt infection. J Neurosurg 2001;94:1019-1020.

14. Gupta N , Park JB, Kranz DA, Wrensch M, Wu IW. Long-term outcomes in patients with treated childhood hydrocephalus. J Neurosurg 2007;106(Suppl 5 Pediatrics):334-339 .

15. Browd SR, Gottfried ON, Ragel BT, Kestle JRW. Failure of cerebrospinal fluid shunts: part I: obstruction and mechanical failure. Pediatric Neurology 2006;234:83-92.

16. Browd SR, Gottfried ON, Ragel BT, Kestle JRW. Failure of cerebrospinal fluid shunts: part II: overdrainage, loculation, and abdominal complications. Pediatric Neurology 2006;334: 171-177.

17. Kestle JRW, Cochrane DD, Drake JM. Shunt insertion in the summer: is it safe? J Neurosurg 2006;105:165-168.

18. Choux M, Genitori L, Lang D, Lena G. Shunt implantation: reducing the incidence of shunt infection. J Neurosurg 1992;77: 875-880.

19. Mottolese C, Grando J, Convert J, et al. Zero rate of shunt infection in the first postoperative year in children: dream or reality? Child's Nerv Syst 2000;16:4 :200-202.

20. Costa BS, Maitrot TD. Prise en charge de l'hidrocéphalie de l'enfant au Brésil. Congres Table Ronde de La SNCLF, Paris, 2001. 